\title{
The Countermeasures of Cultivating Study Responsibilities in College English Teaching
}

\author{
Wang Yong Quan \\ Department of Foreign Languages, Henan Institute of Engineering, Zhengzhou, 451191, China \\ Wangyongquan268@sina.com
}

\begin{abstract}
The combination of social responsibilities and study responsibilities in college English teaching is an important subject in foreign language education in college. It is the essential requirement to connect social responsibilities with study responsibilities, which follows the trend of college English teaching and acts as a very important point toward which the college English education is making an effort. The aim of the study is to promote English quality education. Some methods are utilized as deduction, illustration and so on. The result of the study is that English quality education is enhanced to benefit English education thoroughly.

Index Terms - College English teaching, study responsibility, social responsibility, quality education, countermoves
\end{abstract}

\section{Introduction}

The subject is never researched at home and abroad, and so it is significant to carry on with the study. Such subjects as social responsibilities, corporate responsibilities are frequently researched, but the combined study of relationship between foreign language study responsibility and social responsibilities is rarely performed. The study comes up with some countermeasures to combine study responsibility with social responsibility in foreign language education for the first time, which will help solve the underdevelopment of quality education in English teaching and make up for its insufficiency.

In this study, such methods as analysis, statistics, illustration and deduction are used.

In October, 1998, in "the First Convention of World Higher Education", the document clearly pointed out: "the foremost task of higher education is to cultivate high quality graduates and responsible citizens." Therefore, college English education is not only concerned with language skills but also their comprehensive qualities, and both supplement each other. Contemporary college students are the main body to construct the country and take on responsibility of the time. Their senses of the social responsibility are connected with the failures and successes of college English education, with China's competitive powers in the international arena, with whether college students can take on the responsibility of constructing the national socialist modernism. Most institutions of higher education one-sidedly carry on with the development of language skills, but ignore students' quality education. Larger numbers of English educators have tried to reform it, but it is often easier said than done. Quality education has been on for ages, but it is less effective, since responsibility education is insufficient. As for the problem, measures must be taken to value both to make English education bear fruit.

\section{Both Language Skill Development and Social Responsibility Should Be Paid Attention to}

The cultivation of responsibilities contains both social and study responsibility, and both are connected closely. Without social responsibility, study responsibility would be lost, and vice versa. On the other hand, we always talk about study responsibility, but forget social responsibility in English education, and thus English education is less successful than expected. The combination takes time to develop, as it takes time for each to cultivate. Good and effective methods must be selected, such as shaping-up education and cultivating education. Students must be taught to learn in self-teaching and practice, and meanwhile understand and take on responsibility.[1] College students should be properly taught to be responsible in language and culture studies, naturally getting into the habit of taking on responsibility both in society and study, and enhancing their study responsibility.

Only if social responsibility is fused into English teaching, the language study responsibility can be understood and carried out by students. When social responsibility is transferred into motives of language study, students can naturally have the desire to study English better, which will be the endless sources of study. The sense of responsibility means an essential step for a man to become socialized. It can help improve students' motives of study, interests, learning strategy and personal development. The cultivation of students' responsibility for study is to make the internalized responsibility effective in pushing students on in face of difficulty. It also means good behaviors and habits in society and school.

\section{Cultivation of English Study Responsibility Combined with Chinese Tradition}

English study responsibility cannot be isolated from Chinese cultural tradition. The Chinese traditional moralities are shown as integral ideas to serve society, nation and people, which contain social responsibility. For instance, in Gu Yan Wu's "every man has a duty toward his country" hides sense of social responsibility. In both Mao Tze Dong's "take one's country's destiny as one's own" and Zhou En Lai's "read books for China's rise" are the great social responsibilities, which have set an example for the world.[2] The contemporary college students are the future builders of China and shoulder the great responsibility for China's rise. The abundant resources of patriotism must be tapped from the Chinese 
cultures to be fused into foreign language education to strengthen their sense of study responsibility and build up their consciousness to sacrifice for the country. If you are English majors, too much time and energy devoted in English culture would probably cause you to forget some responsibility valued in Chinese culture. As a Chinese student, the combination of both is proved to be the most effective way of studying English.

\section{Broaden the Horizon of Responsibility on the Basis of English and American Cultures}

The cultivation of study responsibility lies in practice, which should be done down to the earth for foreign language students in China. For instance, English majors should have some time to practice in foreign-funded enterprises as it is scheduled by colleges or arranged in holidays by students themselves. All students' study responsibilities are closely linked to practice of social responsibilities. American college students must have some experiences to work in communities before they are enrolled, and the part-time work must meet the standard set by colleges. It is looked on as a precondition for students to care for others, society and whether they can make contributions to society. It is necessary whatever majors need to be motivated by work for human beings. To strengthen students' sense of morality and responsibility, more and more public schools in America require students to finish the communal work as scheduled before graduation. According to the latest statistics, more than $60 \%$ of teenagers above 12 have fulfilled the duties, which is of great benefit to their health and the formation of a responsible society. While the individualism is dominant in America, more and more people are enthusiastic about social work. The main reason is that volunteers have obtained spiritual and mental benefits, for example, the satisfaction to sacrifice for society, different opportunities to learn the new, enhancement of skills, participation in society, self-fulfillment, emotional satisfaction, individual values and social acceptance. Therefore, cultivation of social responsibilities is necessary for students' study and growth. Practice in foreign enterprises or foreign communities can help form sense of responsibilities and study English better.

\section{Cultivation of Both Responsibilities by Putting What One Has Learned into Practice}

The senses of study responsibility and social responsibility need to be developed in foreign language teaching practice. Teaching is necessarily mingled with social practice, and also a process of consciously shouldering social and study responsibilities. Without social responsibility, study responsibility would be confusing and lost. Undoubtedly, as some college students lack social responsibility and are always selfish and indifferent, their study responsibilities are losing. According to some questionnaires, students' English study responsibilities are the most confusing, as their motivations are becoming more and more discouraging. Many students do not know why and how to learn English in face of difficulties.
Some are only satisfied with passing achievement examinations. The lack of social responsibilities can easily annihilate students' interests, motives and study responsibilities. English study responsibilities need to be freshened and enriched by social responsibilities far more than any other courses, since English cultures and Chinese cultures take time and pains for students to distinguish and harmonize, let alone language skills and acquisition. Thus, in English teaching and study practice, such good qualities as patience, courage, confidence, interests are indispensible, but they are all brought about by the study responsibilities. English teaching and study are essential part of practice, so they are to be accompanied by the responsibilities. Responsibilities and practice cannot be broken down, as both influence mutually and grow together.

6. Combine Western Thanksgiving Cultures with Thanksgiving Education to Cultivate Responsibility Senses.

The fusion of Western thanksgiving cultures with foreign language education helps students be thankful to society and thus is good to the formation of responsibility consciousness. Being thankful is embodied in cognition, emotion and responsibilities for families, countries and society.[3] It can be transferred into endless struggles, motives to master English and real actions.

The education of study responsibility is also a process of cognition, feeling, will and actions. Actually, students' emotional adjustment will certainly affect the education of responsibility and other psychological abilities. In English education, senses of thanksgiving and filial piety are fused, and being responsible for families, countries and society must be evoked to promote responsibility education. "Colleges must carry out systematical education of thanksgiving, strengthen students' awareness of thanksgiving, build thanksgiving cultures on campus actively and teach students to be able to be thankful gradually.'[4]

\section{Join Forces to Build up a Good Language Learning Environment.}

The development of college students' responsibilities for learning foreign language to receive a correct and healthy education is linked to the influences of schools, society and networks.[3] Students are to be enlightened to understand, realize and take the initiative in shouldering responsibility in life and study. Colleges must help students set up lofty ideals, correct outlooks on life, good habits, and historical responsibilities. Combine instruction with management, transform social moralities into students' own actions and foreign language study responsibility will result. All the united forces will guarantee foreign language education to develop in the right way.

\section{Conclusion}

Foreign language education attaches importance to both acquisition of language skills and quality education, but 
somehow quality education cannot be fully valued, and the key reason lies in the insufficiency of responsibility education. When social responsibility cannot be connected with study responsibility, quality education is likely to fail, and foreign language education is to be harmed. Therefore, responsibility education should lie in the core of quality education and especially it must be understood and carried out in college foreign language education and other courses.

\section{References:}

[1] Guo Yong Jiang, Xiao Li Ying: The Principles and Practice of Practice of College Students' Social Responsibility . Research of China's Higher Education, vol. 3, 2004.pp.16-17.

[2] Xia Feng: Study of Social Responsibility Education for Contemporary College Students.Academic Forum, vol. 2,2009.p.28.

[3] Wei Guang Qiu, Yao Chan Zhang: Theories of Political and Ideological Education. Higher Education Press, 1999. p.34

[4] Chong De Su: Comparative Education of Politics and Ideology. HigherEducationPress, 1995.pp.34-35. 